\title{
Splenic Hemangioma
}

National Cancer Institute

\section{Source}

National Cancer Institute. Splenic Hemangioma. NCI Thesaurus. Code C8541.

A hemangioma arising from the spleen. 